\title{
The Awareness of Teachers and Students About Integrative English Language Teaching Approach: The Case of Areka Preparatory School, South Ethiopia
}

\author{
Amarech Alaye Wondimu Tegegne
}

\begin{abstract}
Having an awareness of the theoretical aspect of integrative language teaching approach is important to effectively practice the approach in real classroom situation. The awareness determines the extent to which a teacher can implements the theory. Accordingly, this study attempted to reveal the awareness of English language teachers and students about the integrative language teaching approach. To collect the necessary data for the study, semi-structured interview for six teachers, questionnaire for one hundred seventy students, classroom observation and document analysis were employed. To analyze the collected data, qualitative and quantitative methods of data analysis were employed. That is, data collected through questionnaires were analyzed employing statistical tools such as frequency and percentage using SPSS version 20, while responses obtained from interview was described and discussed. The findings of the study indicate that all teachers and a great majority of students have positive attitude towards the importance of this approach. However, the implementation of integrative language teaching approach in the actual classroom situation was not as expected and their students were not interested to engage in different classroom activities the process of integrative language classes. Based on the findings, recommendations are forwarded to improve the implementation of integrative language skills teaching approach.
\end{abstract}

Keywords : Awareness, English Language, Integrative Language and Teaching Approach.

DOI: $10.7176 /$ RHSS/9-15-03

Publication date: August $31^{\text {st }} 2019$

\section{Background of the study and Rationale}

With the spread of English as a lingua franca and as the medium for world-wide broadcasting of information and knowledge, in many cases, the pragmatic objectives of language learning emphasize the importance of integrated language skill teaching and flexible instruction. (Celce-Murcia, 2001). In general, insight on current language curriculum, teaching reading is typically associated to instruction on writing and vocabulary, teaching writing can be easily tied to reading and grammar, and speaking skills readily lend the learners to teaching listening, pronunciation, and cross-cultural pragmatics (Hinkel, 2001). Meanwhile, the current models of integrated teaching of the four language skills have the objective of developing learners' fluency and accuracy, as well as their socio cultural communicative competence requiring and adapting the language from context to context and from genre to genre.

Besides, the effective implementation of integrative language teaching approach requires different things such as sufficient materials, appropriate number of students, awareness of the approach, positive attitude of English language teachers and students. Therefore, it is important to investigate the awareness of English language teachers about integrative approach of language skill teaching. In addition, the attitude of English language teachers and students about integrative approach of language skill teaching can also affect the practice of integrative language teaching approach. Accordingly, it is important to explore the attitudes of teachers and students about the new approach of language teaching.

\section{The Analysis and Discussion of Data}

\subsection{English Language Teachers Awareness of Integrative Language Teaching Approach}

Semi structured interview was held with English language teachers to reveal their awareness of integrative language teaching. The teachers were interviewed on approaches of language teaching, meaning, advantages and disadvantages of ILTA. Besides, they were interviewed on their roles and the role of students in ILTA. The data obtained with this regard are presented as follows.

First English language teachers were asked how many approaches are there to teach language skills. In this response, three different views were reflected. Specifically, two teachers ( T1 and T4) said that there are two approaches of language teaching, integrative and segregated language teaching approach.

The other three teachers(T2, T3 and T6) mentioned that there are different approaches that are used to teach language skills such as natural approach, oral approach, grammar translation method, direct method, audio lingual method, communicative language teaching approach, the silent way, task based method, content based method, total physical response and suggestopedia. These teachers mentioned specific language skills teaching 
methods

On the contrary, to the above two views, T5 said that there are four language teaching approaches(i.e. reading approach, listening approach, speaking approach and writing approach) used to teach language skills.

From the above responses, it is noted that English language teachers recognized that there are different approaches used to teach language skills. However, the teachers are in different in naming the specific language teaching approaches.

Besides, English language teachers were interviewed to explain "what does integrative language teaching approach mean to them". In responses, the teachers provided their own definitions which are almost similar in meaning. Integrative language teaching approach is teaching of language skills associated to each other. For example, T1 said that when a teacher lectures in a student centered way, he/she communicates with his/ her students (speaking and writing short notes on the board and read on the board aloud). In this case, his/ her students listen to the teacher, copy and read the note on the board and articulate with their teacher. Similarly, T2 added that in language teaching and learning, topics should be designed for discussion and action, classroom activities should be supportive with the real life situation. These help to enable students to use the language for real world communication purposes.

The teachers were further asked to list the advantages and disadvantages of integrative language teaching. According to English language teachers, the major advantages of integrative language teaching approach are:

$>$ It will advance students language skills, built their capacity, they will effectively pass their exam when they are thought via ILTA.

$>$ It widely opens the door for the students to master their language skills.

$>$ It enable students use the language for real life communication purposes.

$>$ It exposes the learners to authentic language learning and gives students true image of English language learning as needed for real world communication.

$>$ It gives awareness to learners that English is a means of interaction and sharing of opinions among people.

$>$ It allows teachers to shape learners' progress in multiple skills at the same time and motivate students.

$>$ It enhances cooperative learning in the classroom, promotes students communicative competence, develops the overall language skills of the students.

On the other hand, the teachers, listed the following as the disadvantages of ILTA.

$>$ It requires a lot of time because each student should practice each language skills properly. Thus, it can be said that the process is time consuming.

$>$ It requires well qualified(informed) teachers.

$>$ It needs sufficient materials in addition to students textbook and teachers guide.

$>$ It needs students active participation, especially, T5 stressed that its implementation depends on the students and teachers level of knowledge. He raised one example of disadvantage of ILTA. "If most students are passive to perform different activities, the teacher is enforced to dominate the class without participating his/ her students". So, it needs active students.

On the contrary, one teacher (T4) believes that "integrative language teaching approach saves time in a given lesson rather than treating each skill separately". By doing so, all the macro and micro skills are taught unconsciously.

From the above responses, it can be inferred that the majority of English language teachers seems to have an understanding of the meaning, advantages and disadvantages of integrative language teaching approach.

According to (Shanghais,2012) teachers should know their responsibilities like preparing various kinds of activities which are appropriate, effective and relevant to the teaching of language skills and which will best meet the students needs and expectations. Based on this fact, English language teachers were asked about their roles' in integrative language teaching approach. Teachers stated that they have different responsibilities. For example, T2 said that: "My role in ILTA is to associate which language skills are related to with which. That means vocabulary, spelling, pronunciation, syntax, meaning and usage. So these linguistic relations should be first of all understand by the teacher".

He stated that pairing and grouping according to students' interest or level of understanding are his role. With this regard T2 said that, "I am responsible to create a sense of collaborative learning". Besides, T6 stated that his role as follows: "I have different roles when I teach language skills integratively in the class. For example, when I teach vocabulary and speaking, I encourage the students how to spell and pronounce different words during the lesson."

The above responses revealed that teachers seem to know their responsibilities to teach language skills integratively.

The next question that the researcher asked English language teachers concerning their students' role in the integrative language teaching approach. The responses forwarded were almost similar. Thus, it can be summarized and presented as follows. Their roles include: 
$>$ Students are expected to play the role of practicing the language skills guided by the teacher.

$>$ They are expected to be attentive, good listeners, eager to learn, share their view to others class mates.

$>$ Students should monitor and evaluator of their own learning. This means students are responsible for their own learning.

$>$ Students are responsible to asking and answering questions, to perform different tasks ordered by the teacher cooperatively or individually.

One of the teachers (T2) confirmed this view as follows; "It is widely agreed that learning takes place when activities are engaging and memorable. In such cases, even silent learners get the chance to express themselves in a more participatory way. So students are expected to play active role by participating in small groups, pairs or individually".

From the analysis of interview data, we can conclude that English language teachers have an understanding of the meaning, advantages and disadvantages of ILTA. Besides, they seem to have an awareness of their responsibilities in the ILTA and what their students are expected to do during this approach. The awareness of English language teachers about ILTA facilitates teachers implementation of ILTA in the actual English language classroom. This finding agrees with what Alemayehu, (2008) stated. In line with this Alemayehu, (2008) noted that teachers with high theoretical orientations and understanding of the advantages of integrative language skills teaching, implement the it effectively.

\section{2. The Awareness of Students about Integrative Language Teaching Approach.}

Close ended questionnaire was used to gather data from sample preparatory students to reveal their awareness of integrative language teaching. Below is the summary of students' responses on the issue.

Table 1: Students' Responses on their role and the role of their teachers in ILTA

\begin{tabular}{|c|c|c|c|c|}
\hline \multirow[b]{2}{*}{ No } & \multirow[b]{2}{*}{ Items } & \multirow[t]{2}{*}{ Options } & \multicolumn{2}{|c|}{ Responses } \\
\hline & & & No & $\%$ \\
\hline \multirow{9}{*}{1} & \multirow{8}{*}{ 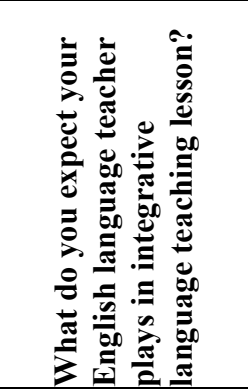 } & $\begin{array}{l}\text { A. Facilitate the classroom situation and create conducive } \\
\text { classroom environment }\end{array}$ & 5 & 2.9 \\
\hline & & B. Manage the class & 8 & 4.7 \\
\hline & & C. Ask question and give correct feedback & 12 & 7.1 \\
\hline & & D. Write appropriate note to your learning & 20 & 11.8 \\
\hline & & E. Give a certain class activities and discuss with students. & 8 & 4.7 \\
\hline & & $\begin{array}{l}\text { F. Give assignments and project works you to teach language } \\
\text { skills integratively }\end{array}$ & 29 & 17.1 \\
\hline & & G. All of the above & 85 & 50 \\
\hline & & H. I don't know his/her roles & 3 & 1.8 \\
\hline & & Total & 170 & 100 \\
\hline \multirow{8}{*}{2} & \multirow{8}{*}{  } & A. Ask and answer questions & 8 & 4.7 \\
\hline & & B. Listen attentively & 51 & 30 \\
\hline & & C. Take notes & 6 & 3.5 \\
\hline & & $\begin{array}{l}\text { D. Perform group work with group } \\
\text { members }\end{array}$ & 6 & 3.5 \\
\hline & & E. Reflect your view & 4 & 2.4 \\
\hline & & F. All of the above & 87 & 51 \\
\hline & & G. I don't know my roles & 5 & 2.9 \\
\hline & & Total & 170 & 100 \\
\hline
\end{tabular}

Table 1 presents the responses of students about English language teachers and their role in the integrative language teaching. As can be seen in Table 1 (see item 1), 85 (50\%) students responded the roles' of the teacher in the actual integrative language teaching class room is facilitating positive classroom environment, managing the class, asking questions and giving correct feedback, writing appropriate notes, giving classroom activities and discussing with students and giving assignments and project works to teach language skills integratively. Besides, $29(17.1 \%)$ students said that the teacher is responsible to give assignment and project work and $20(11.8 \%)$ students replied that writing appropriate notes to the students is the role of their English language teachers. In addition, 12(7.1\%) of students stated that the expected role of their teacher is asking and answering questions, $8(4.7 \%)$ students replied that to manage the class as well as $5(2.9 \%)$ students said that the roles of their teacher is to facilitate the situation and create conducive environment. Furthermore, $8(4.7 \%)$ students replied that the role of their teacher is to give different activities and discuss with students teaching language skills integratively. However, the remaining, $3(1.8 \%)$ students responded that they do not know the roles of their teacher in integrative language teaching classroom. 
Thus, it can be inferred that students seem to know the role of their teacher in ILTA. Parallel to the students response, English language teachers also listed similar roles' and students' role during integrative language classes. Similarly Scholars like Shanghais(2012) confirmed that in integrative language teaching approach a teacher has responsibilities of organizing various kinds of activities which are appropriate, effective and relevant to the teaching of language skills and which will best meet the students' needs and expectations. Besides, the teacher should give clear instructions, as manager and organizer in actual classroom situation. This agrees with the finding of this study.

In item 2 (Table 1) students were asked about the roles that they are expected to play in integrative language skill classroom. In response, 51(30\%) students responded that their role is listening attentively and $8(4.7 \%)$ students said that their role is asking and answering questions during ILTA. Besides, 4(2.4\%) and $6(3.5 \%)$ students replied that their roles are to reflect their views and discuss with group members respectively. Similarly, $6(3.5 \%)$ students responded that their role is to take note in actual classroom situation. On the contrary, $5(2.9 \%)$ students said that they do not know their roles' during ILTA, 87(51.2\%) students reported that their roles while the teacher is teaching language skills integratively are asking and answering questions, listening attentively, taking note, performing group work with group members and reflecting their your view. From the above data, it can be said that the students are expected to play various roles in integrative language teaching approach lessons.

Generally, the analysis of data obtained from teachers' interview revealed that teachers have adequate awareness about the meaning, advantages and disadvantages of integrative language teaching approach. Similarly, students also know their role and the role of their teachers in ILTA. These would facilitate the implementation of ILTA in the actual classroom context. This result agree with Larsen- Freeman, (1986). With regard to the role of students, Larsen- Freeman stated that students are expected to play in their own role in integrative language skill learning to engage in different classroom activities, negotiating meaning, should be managers of their own learning.

\section{Findings of the Study}

Regarding teachers' and students' awareness of the teaching of language skills through integrative language teaching approach the following findings were derived:

* The study revealed that teachers have an awareness about the meaning, advantages and disadvantages of implementation of integrative language teaching approach.

* Besides, teachers seem to have an awareness of their responsibilities in the integrative language teaching approach and what their students are expected to do in this approach.

* Similarly, students also know their role and the role of their teachers in ILTA.

\section{Recommendation}

- It would be helpful if teacher training institutions (colleges and universities) be aware of the gap between the teachers' theoretical knowledge of integrative language teaching approach and their classroom practices. So, they should train teachers on both the theoretical and practical aspects of integration of language skills in the actual classroom situation.

\section{References}

Alemayehu Negash (2008) "A study of the practice of Integrating Language skills in the teaching of English." Unpublished MA Thesis Addis Ababa University.

Celce-Murcia, M. (Ed.). (2001). Teaching English as a second or foreign language (3rd ed.). Boston: Heinle \& Heinle.

Hinkel, E. (2001). Building awareness and practical skills for cross-cultural communication in ESL/EFL. In M. Celce-Murcia (Ed.), Teaching English as a second or foreign language (3rd ed., pp. 443-458). Boston: Heinle \& Heinle.

Larsen-Freeman, D. (1986). Techniques and Principles in Language Teaching: Oxford University Press. Shanghais, Y.(2012) .Teachers ${ }^{e e}$ Roles in Autonomous Learning : 2012, Vol. 3, No. 2 Mcrothink institute :China. 